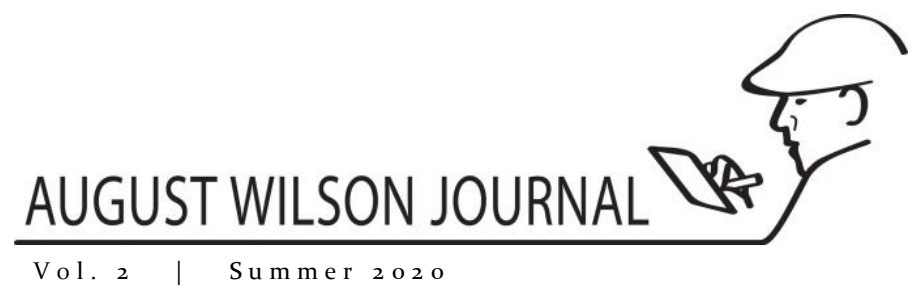

\title{
Unlocked Minds: August Wilson's Suspects, Ex-Cons, or Soon-to-Be Convicted Characters in his American Century Cycle
}

\author{
By Skyler Easton Saunders \\ Independent Scholar \\ "The greatest spirit of resistance among blacks is found among those in prison." \\ - August Wilson, Interview with Bill Moyers
}

\begin{abstract}
This essay is a meditation on the significant number of carceral references made by the late Mr. August Wilson in his American Century Cycle. It sets out to delineate the various instances where Mr. Wilson mentions the many associated pains, both mental and corporal, that crop up in lives of his characters, related to prisons, jail, work farms, chain gangs and other forms of detainment and imprisonment.
\end{abstract}

Keywords

August Wilson, jail, prison, incarceration, Black Lives Matter, George Floyd, Breonna Taylor, Parchman Farm, American Century Cycle

Within this essay, the idea of incarcerated, about-to-be-imprisoned, or currently-lockedup Black men in the plays of August Wilson is explored, with some consideration given to how the Twentieth Century Cycle adds immediate realism and cultural understanding to such contemporary events as the murder of George Floyd ${ }^{1}$ by police and the Black Lives Matter movement. The various interactions which occur on the page, stage, and screen ultimately can be sourced to the harsh realities faced by African American men, including days spent on the infamous Parchman Farm ${ }^{2}$. This mindset of oppression and incarceration is at the forefront of every sentence that Mr. Wilson wrote. He knew that the sprit and soul of Black men living in America would bear its fruit in the speech and actions of his scarred characters, both in a physical way and in minds and hearts of audiences and readers. Wilson understood the pain and anguish and fury evident in his male characters. They are the men who live and

\footnotetext{
${ }^{1}$ George Perry Floyd, Jr. was a Black American man killed during an arrest on May 25, 2020 in Minneapolis, Minnesota. A white police officer knelt on Floyd's neck for nearly eight minutes. The officer, Derek Chauvin, 44, is charged with murder and manslaughter. The charges carry a combined maximum 35-year sentence.

${ }^{2}$ Often called "Parchman Farm," Mississippi State Penitentiary (MSP) is a maximum-security prison farm located in Sunflower County, Mississippi. Parchman is the only maximum security prison for men in the state of Mississippi and is the state's oldest prison.
} 
breathe the rhythmic and poetic syllables related to the theme of oppression in his plays, echoing the lives of actual Black men who are incarcerated in the United States at this moment. The cost of this coordinated program of incarceration over the centuries cannot be effectively measured. In the face of that incomprehensible devastation, however, Mr. Wilson shows colossal bravery to depict the lives of these men honestly, actually using the word "jail" in every single play. At this writing, in July of 2020, with millions or Black men locked behind The Wall in America, we look to leaders like August Wilson to communicate this devastation, and we must hold up his work as a model to press for change. So for all of the souls of Black men who have been, are, or will soon be on lockdown, we draw on the words of King Hedley II: "I got honor and dignity even though some people don't think that. I was born with it." Hang on to your honor. Change is coming.

Upon hearing the name August Wilson, people's responses usually reflect the definition of his first name: Illustrious. Esteemed. Respected. The late poet and playwright born Frederick August Kittel Jr. spent decades carving an immense sculpture of Black America. One key characteristic found in almost all of his American Century Cycle is the appearance of at least one character who either is a suspected criminal, an ex-convicted felon, or is assumed headed to prison. Each of these characters is more often male (Aunt Ester is an exception). The men who experience the corrections system carry psychic and physical scars. They are at times angry, bitter, standoffish, and belligerent towards other characters. They often seek to rectify what they did wrong. Despite or maybe because of the fact that they witnessed subhuman living conditions, they engender various acts of fiery idealism and still show simmering wrath. Their

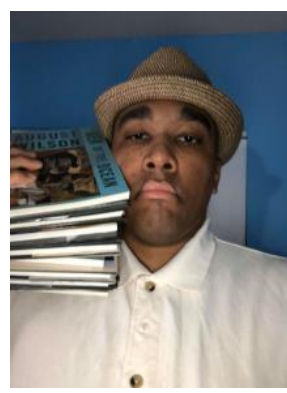

Mr. Skyler Saunders, Independent Scholar coolness is sometimes a ruse to cause someone to think that they are not going to boil over and lash out at anyone. It helps them survive in a hostile environment.

Interestingly, a number of former prisoners, many of them African American, participated in the restoration of Mr. Wilson's home in Pittsburgh's Hill District. The leader of the project, Stephen Shelton, found that because they worked on the August Wilson House "the [ex-convicts] "really started looking at their jobs differently" (Bauder). If current prisoners like these twenty eight inmates of East Jersey State Prison in Rahway, New Jersey, can, according to author and teacher Chris Hedges, "have their song" and can work to refurbish Mr. Wilson's childhood home and conduct readings of his plays while still behind bars, then there must be some sort of connection to the power of the fictional characters who struggle to stay out of the carceral system or at least maintain dignity while within the prison walls.

In his plays, August Wilson demonstrates a seemingly unprecedented number of Black people within the criminal justice system. From Clarence "Booster" Becker in Jitney to Troy Maxson in Fences, characters familiar with the prison system abound. The female characters are also familiar with the cycle of incarceration (from King Hedley II):

RUBY: What you and Mister up to? Tonya said you was selling refrigerators. You all out there stealing refrigerators, you goin back to jail.

KING: See, there you go. You don't know where we getting them from. We selling them. We ain't stole them.

RUBY: Somebody stole them.

KING: I ain't asked the man where he got them from. He say do I want to sell some refrigerators. I ain't asked him where he got them from. I asked how much he was gonna pay me.

RUBY: What kind is they?

KING: They GE refrigerators. That's the best refrigerator on the market. Mellon got a GE refrigerator. 
S A U N D E R S: U N L O C K E D M IN D S: A U GU S T W I L S O N'S

SUSPECTS, EX-CONS, OR SOON-TO-BE CONVICTED

CHARACTERS IN HIS AMERICAN CENTURY CYCLE

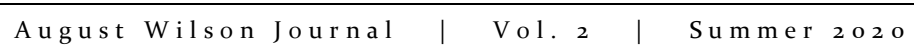

RUBY: YOU going back to jail. The police gonna find out. The police know everything.

KING: They don't know everything.

Perhaps his greatest strength appears when Mr. Wilson bares the souls of these characters to express the idea that these Black men are human beings. In fact, he once said, "The most valuable Blacks are those in prison. Those who have the warrior spirit, who have a sense of being African. They got for their women and children what they needed when all other avenues were closed to them." With this in mind, they become fully human. Their flaws and shortcomings become part of their character. The fact that they attempt to overcome their drawbacks in these plays allows the audience to empathize and understand the ideas behind their lives. So, when the lights dim and the stage illuminates, the audience sees their own pains, struggles, and joys in the men, especially those who have been in a certain kind of physical bondage. In the case of Hedley II, he initially tries to take the course of entrepreneurship by selling refrigerators. Unfortunately, he falls in with a group of criminals, which, for Wilson, is indicative that pretty much any efforts by a Black man to work hard and earn a living are blocked by systemic racism at almost every turn. Even attempts at entrepreneurship are, from the start, illegal.

In his plays, Mr. Wilson seeks to find the meaning at the root of this disparity. As the scale of this gulf has fluctuated over the ten decades of the Cycle, Mr. Wilson shows that the time period does not matter. In America, Blacks have had to contend with the justice system. Through his work, he's been able to show the humanity of men of color who have been affected by the justice system. He has also portrayed them as angry, vicious monsters at times but also as stable men who just want to get another chance at life. But the underlying theme to all of his plays is the idea of what it's like to be free in a world that expects you to either go to a cage, stay in a cage, or go back to one. The bird is the man who decides to fly. Every line of monologue that is spouted by a man who has or will (presumably) experience the cold hand of justice brings his consciousness to the fore.

\section{Clarence "Booster" Becker (Jitney, 1979/1996)}

In, Jitney, Booster has just returned from a twenty-year prison stint for murder. The facts surrounding the case seem completely plausible. He kills a white woman who accuses him of a rape that he did not commit. Wilson writes, "the first day out...he went over to that gal's house and shot her dead right on the front porch." He essentially commits thievery against his own life. He is sentenced to death but his case is commuted, ultimately. After he is released from prison, he attempts to foster a better relationship with his father, Jim Becker. Because of his record, Becker is filled with anger and resentment towards a son that he senses ruined his whole life out of senseless vengeance. The two never reconcile as Becker dies on the job at the mill, leaving Booster as heir apparent to the jitney station.

In Kimmika L.H. Williams-Witherspoon's piece, "Challenging the Stereotypes of Black Manhood: The Hidden Transcript in Jitney," she outlines the reason why Clarence becomes Booster by discussing the "male ritual of incarceration." She writes:

Although Jitney does not represent visually the regimented dynamics of incarceration or indicate the huge percentage of African American men forced to waste caloric and intellectual output in a non-productive community, the repeated references to the twenty years Booster spent in prison represents incarceration as a negative end product consistent with one stereotype of Black manhood. (45) 
Booster, having served his sentence, now has the chance to lead the jitney station, but his contentious relationship with his father is fraught with pain and anger. The two men never see each other as someone to respect. Upon the death of Becker, Booster exudes the power and the glory of attempting to stand in his father's shoes. He has shouldered up the burden of running a station of his own and accepted the circumstances which come along with such a position. What prison has done to him psychically is erode away his sense that his father truly loved him. It took Becker's demise for him to realize that love. The respect that the two men could not exhibit in life has to be carried on with Booster's role as leader of the jitney station.

\section{Levee (Ma Rainey's Black Bottom, 1982)}

All of the bluster and rage and anger that Levee expresses could fill two plays. But the trumpeter known as Levee in Ma Rainey's band exhibits the frustrations, exploitations, and misplaced hate relating young Black men in America. He tells a tale about how white men chastised and mocked a man of the clergy. This leads Levee to deliver a furious diatribe against the "white God" that other Blacks are so enamored with, for what reason he knows not. Kyle Smith speaks of Levee's blasphemy which leads to violence. In this case "he believes in the context of Black suffering that God could not exist except as a white racist." In particular, he describes how his mother was raped by a pack of white men and that he bears the physical and psychic scars of the incident. While containing all of this pent-up fury, he gets into a squabble with trombonist Cutler. In the heated discussion which becomes a melee, Levee stabs Toledo, the piano player. The lights go dark and the curtains close. One can only assume that Levee will be tried for murder for his acts and destroy his entire future.

Despite the fact that Ma Rainey is the title character, the real protagonist of the play is Levee. What fuels him are the conditions of fighting racism, developing what would become of the next incarnation of the blues and jazz, and his ability to convey the power of youth. Levee brings out the horror stories of a life marred by tragedy. Through his strength of character, he's able to endear himself to a woman like Dussie Mae. What drives Levee is a burning hatred for the white man and an atheist streak that is blemished because it lacks a moral background. He lives in the rage of the moment and never fully engages with his psychic scars but allows them to fester and scab over. He scratches at them and allows them to bleed when he delivers his fiery monologues.

He is full of anger because of his past. His slaying of Toledo is the death knell to his aspirations. It is suspected that he will either commit suicide or be tried and sent to the penitentiary for his murderous ways. This represents the Black youths that face the decision to do away with their own lives or to face the judge and the prison walls. Levee sacrificed his musical gift in killing Toledo. Levee must accept the facts of reality as a result of his ignominious actions.

\section{Troy Maxson and Jim Bono (Fences, 1985)}

Disgruntled, befuddled, and confused, yet still engaging, witty, and strong, Troy Maxson from the play Fences is convicted of killing a man accidentally while engaged in a robbery. When he returns to life outside "the wall," he is at times humorous and at other times thoroughly bitter about his lot in life. Bono represents a piece of his past in jail that carries into the present. Positioned to be a star negro baseball player like Jackie Robinson, Maxson never gets that break. He believes that players like Josh Gibson could've gotten a better shot at Major League Baseball than Robinson. His ethics mixed, now honest at being a garbage man but who cheats on his wife, he somehow instills in his high school aged son the value of always making sure that someone is doing right by him.

Maxson's past as a member of the general population behind bars propels his acrimony as well. The result of pent-up frustrations did not, however, deter Maxson from 
continuing on through life and starting a family (or families). He has gained some idealism about the world and can still relate a yarn with aplomb. But prison life has affected him, still. With few options other than being a garbage man (an honorable profession) on his horizon, he yearns for his halcyon baseball days. He seeks to make amends with his eldest son and still be a presence in the life of his youngest. As Anissa Janine Wardi illustrates, Lyons is the single character in Wilson's oeuvre who is imprisoned while the play is set in motion. Wardi points out that "many if not most of the men share the experience of imprisonment, and thus carceral places occupy an important rhetorical space in Wilson's dramaturgy."

Penitentiary life has placed a spell of disenchantment on Maxson. He has disagreements with his wife Rose and his sons Lyons and Cory. This all stems from the hurt that he still carries around with him like a warrior who experienced psychic scars in battle. That's why he's so preoccupied about death. August Wilson demonstrates that Maxson has "wrestled with Death for three days and three nights...." Maxson still has a center of morality, if not challenged by his own inability to cope with reality. That's what prison does to the mind. It holds onto the inmate even in the years that go by from first being locked behind the gates. "Fences" represent the boundaries that Maxson has set up from his days locked up to the opportunity that he created for himself to keep swinging for them, even if the ball goes infield.

\section{Harold Loomis (Joe Turner's Come and Gone, 1984)}

Technically, Loomis has not been convicted by the American legal system. Instead, he is kidnapped in the American South and forced to work on a chain gang. Hunched over a kitchen table just like in Romare Bearden's painting, Mill Hand's Lunch Bucket (1978), Loomis has his song stolen from him. Hongmei Zhang contends that Loomis has fallen "prey" to the Tennessee Governor. Zhang continues saying, "He could possess and exploit Blacks to work for him without being punished." As this applied to Loomis' situation, the struggle to rise up from the chain gang of a corrupt government echoes the fight against injustice. For seven years, he is compelled to complete back-breaking, mind-numbing, soul-crushing labor for a man who illegally rounds up Black men to fulfill his tasks. The significance of the song contains the notion that every man and woman ought to have something to strive for, to live for, in this world. Loomis finds some kind of song as he rips open his shirt, exposes his chest, and proceeds to slice it, saying, "I'm standing, now!" This shows a release from the shackles that bound him.

Now, Loomis being on that chain gang was no fault of his own, but he lived the life of a convict. He had to toil and sweat under the blazing sun while driving stakes into rails. He had to endure the indignities of a man without freedom just because of the hue of his skin. The real life story behind Joe Turner is dark and vicious. In actuality, the brutal truth of fathers, sons, brothers, nephews, and grandsons who were stolen and forced to work for a nefarious white man post-slavery underscores the search for self-meaning and finding one's own song. It is a harsh case to digest as Black boys and men never had the chance to refuse to labor for this man.

This would steal anyone's song. To self-define and self-reflect, it would be a nearimpossible task to regain one's song and lift it high to the sky. With an atheist sensibility that rivals Levee's, Loomis questions the existence of a "Holy Ghost." Fortunately, Loomis finds his song and is freed from his past and allowed to prosper in the future.

\section{Sterling (Two Trains Running, 1990)}

The one thing that is constant with a string of characters that have just returned from the penitentiary in an August Wilson play is that there exists some redemptive quality in the individual. In Two Trains Running, Sterling is just discharged from prison for 
committing a bank robbery. He has within him a sense of what is right and wrong after being rehabilitated. All he wants is an opportunity. He finds it at Memphis Lee's restaurant. What Wilson is showing in this instance is the fact that a man can change from whatever ogre he once was and fashion himself to be a model citizen.

Sterling persists as an ambitious man after being let out from prison. He wants to be like Memphis Lee and own his own establishment. The prison walls did not deteriorate Sterling's soul. He holds onto the sensibility that the Black man can succeed in this country through smart work and devotion. He has been rehabilitated in the eyes of the law, but he still seems a little off balance. The time that he spent behind the wall only served to try to break his spirit, but he had enough soul to defeat anyone or anything who ever tried to break him. As a free man, he has the opportunity to bring his life into perspective. He has the option of being an entrepreneur like Memphis and continuing his life without worrying about going back to jail. Cynthia L. Caywood and Carlton Floyd acknowledge that, unlike Hambone, Sterling must be able to make up for his past misdeeds.

Aunt Ester exemplifies this idea, according to Caywood and Floyd: "Aunt Ester incarnates a key Wilson idea-the need for African Americans to embrace their cultural context....” This relates to Sterling as he must navigate a new life if he wants to chart a course of success in America. However, it does appear at the end of Act II Scene V that he is headed right back to the prison walls for apparently stealing a ham. Here, the idealism of one Black man's death leads to the implied future confinement of another. As August Wilson positions him, Sterling simply says, "that's for Hambone's casket" while blood streaks his face and hands. It is a spiritual payback. His desperate attempt at bringing Hambone justice is an ironic and tragic reminder of the reality of not receiving one's own due. Hambone had painted that fence. He performed excellent work. However, Lutz never hands him his ham but offers a chicken instead. Wilson here emphasizes the thought that one must never settle for something of lesser value when the real prize, the greater one should be afforded. Sterling, in his mind, feels like he is doing an act of honor by being a thief and giving to Hambone in death what he could not acquire in life. While what happens to Sterling is left to the audience's imagination, the prevailing conclusion is that he ends up in prison for his actions. Though he may have been justified in his intentions, the way that he carried out this crime pushes him over the edge of morality.

\section{Uncle Doaker, Boy Willie, Lymon Jackon, Lymon's Daddy, L.D. Jackson, and Wining Boy (The Piano Lesson, 1992)}

The men who have experienced the brutishness of Parchman Farm still sense in their minds the bitterness of being locked down in a cell. Originally played by Charles $\mathrm{S}$. "Roc" Dutton, a man who served seven years for a manslaughter charge, the actor injects into his role as Boy Willie some of his hectoring from being locked down for nearly a decade. August Wilson posits through Lymon that Boy Willie is going to "end up back down there on Parchman Farm."

Each of the men listed above try to work through their mental wounds by displaying the blues. "Berta, Berta" is a work song that is rife with struggle and pain. But just like the blues, it is actually philosophical and life-affirming. The song tells about a prisoner seeking to ensure that his beloved Berta marries a man better than he. Most of the men who have been on Parchman Farm still harbor the turmoil and unease that go along with prison life. Toni Morrison, in the foreword to The Piano Lesson points out that the men recognize the prison like "they know their hometown." " [Wining Boy's] wandering seems necessary not just for his career but to avoid confinement." The late Pulitzer Prizewinning author continues by saying, "Lymon's refusal to return home arises from the fear of the sheriff who is looking for him." Miss Morrison elucidates the closeness of the men forged through their suffering on Parchman Farm. She then describes how Wining Boy is like any Black man in America, focused on life without being afraid of the police. 


$$
\text { August Wilson Journal | Vol.2 | Summer2o2o }
$$

As the men sing the song, their frustrations and anger at the torment of having been subjected to inhumane conditions are expressed through one of Wilson's famous Four B's ${ }^{3}$--in this case the Blues--with power and nobility, despite the difficult experiences they have endured. The specific crime of looting wood--something necessary to stay warm-from white men leads to the death of Berniece's husband Crawley and the sentences of Willie and Lymon. With the highest number of felons incorporated in an August Wilson production, The Piano Lesson encapsulates the years of anguish as lived by most of the men in the play.

\section{Floyd "Schoolboy" Barton Hedley (Seven Guitars, 1996)}

At the outset of Seven Guitars, Floyd "Schoolboy" Barton reports committing a less heinous crime by Wilson's standards but a crime nonetheless: vagrancy. Despite this common and exploitative method for detaining and imprisoning poor [Black] men in America, Barton holds on to his dream, which is related, not surprisingly, to music. Caywood and Floyd write, "Floyd pins his economic hopes on making another hit record" but this dream is a dream deferred and never comes to pass. Toward the end, Schoolboy gets into a struggle with Hedley who, with a quick blow to the throat from a machete, kills Floyd Barton.

The machete scene further underscores Mr. Wilson's portrayal of mentally unstable characters. Some are benign but others can be deadly. Hedley slaughters a rooster before the scene where he kills Schoolboy, foreshadowing the whole thing. The makeup of the entire scenario consists of a man who is not altogether there psychologically and precipitates the death of someone. Again, like in other plays, it is only a thought as to whether Hedley faces jail time for his misdeeds. But the fact remains that the blood that is spilled can only link back to Hedley. One can surmise that because of his mental state, Hedley probably saw the inside of an institution for the criminally insane.

The scenes which follow do not indicate any arrests, only suspicion of Hedley's guilt by a character named Canewell. Perhaps one day Hedley will be found out and also spend time in the penitentiary, but at the conclusion of the play, he goes unpunished, suggesting, possibly, that Black-on-Black violence is one of the few crimes where Black men go unpunished.

\section{King Hedley II, Mister, Elmore (King Hedley II, 1999)}

After a seven year prison term, King Hedley II heads back into "the world" and seeks to re-establish himself. He bears a scar on his face from the scuffle that landed him behind bars, despite his protests that he had killed the man defaced him in self-defense. Now, King must deal with prospects of finding a way in life by hustling stolen refrigerators to finance a video store. He also must contend with a wonderfully independent wife, Tonya, who professes to abort King's child. He opposes based on the belief that there will be a King Hedley III. It doesn't matter though. In the end, King receives a bullet, and after all of his time scheming and planning, he dies never knowing whether Tonya delivered the baby or not. Wilson suggests that Tonya is not "going through with" having another baby in one of the bleakest times in American history, the 1980's.

King Hedley II just wants to get his life back to some sense of normalcy. What is apparent is what Kyle Smith calls King Hedley II seeking a "matter of honor." Stealing refrigerators is an unlawful act. The aspiration is still there. He views his actions as only supplying his legitimate aims. He wishes to carve out a better life for himself and for his family. This is the metaphor brought to the fore in the 1980's backdrop. King Hedley II just

\footnotetext{
${ }^{3}$ In a 1999 interview in The Paris Review, Mr. Wilson cited his major influences as being the 'four B's': the blues was the 'primary' influence, followed by Jorge Luis Borges, the playwright Amiri Baraka and the painter Romare Bearden.
} 
wants to put his penitentiary days behind him. He still feels bitter by the fact that he is seen as a convict when he acted in self-defense. His death is another metaphor for the demise and fracturing of the African American family during this tumultuous decade.

\section{Caesar Wilkes, Solly Two Kings and Aunt Ester (Gem of the Ocean, 2003)}

Here, one would only have to suspect that Caesar kills Alfred "Solly Two Kings"

Jackson by shooting him down like a dog in the street. But the real issue is with Aunt Ester being jailed. She represents the past, present, and future of the Cycle, even in death. For her to be burdened by the dictates of the state even for a short stint based on the fact that she helped Solly to escape and blocked an arrest shows the power of the American carceral system. This shows a bit of irony in the fact that the oldest and wisest character in Wilson's canon did not show enough wisdom to be rid of fetters herself. Wilson must have wanted to illustrate that no one is above having the cold steel of justice wrapped around their wrists, as Aunt Ester is the only woman to be placed in police custody.

The "despicable practices" as Caywood and Floyd ascertain lead Caesar down a path of moral destruction. They continue by writing, "the extensive devastation African American males have faced by systemic institutionalized oppression" bear heavily on his head. In the aftermath of the play's events, there is no talk about whether Caesar will face justice. But that is the essence of the Cycle. The wondering which takes place regarding what happens to these characters sketched so richly, after horrendous crimes like the murder of Solly is what is so profound. Caesar escapes justice for the death of Solly Two Kings, whose crime was burning down the mill. "I burned it down" Solly says. This is a window into the soul of Solly Two Kings as a criminal who could face a severe prison sentence, this time for arson. The braggadocio that Solly exhibits is visible with his explanation of how he will be remembered regardless in what capacity: good or ill, fame or infamy.

Black Mary disowns Caesar, yet she gives no indication as to ever intending to turn in the man. Eli looks for Caesar but never minds the case altogether. Caesar's position, along with his quick tongue and evasiveness, will likely be sufficient for him to elude punishment. In all Aunt Ester, Caesar, and Solly Two Kings form a triptych of criminal activity in Gem of the Ocean with varying degrees of consequence.

\section{Sterling Johnson, Elder Joseph Barlow (Radio Golf, 2005)}

Sterling Johnson is a reformed inmate who served time for robbing a bank (again). He did it as Mr. Wilson so eloquently suggests, "to know what it's like to have money." What is at work here is the false sense that appropriating money will lay the groundwork for a mansion of happiness. In Sterling Johnson's case, the blueprint for riches is torn to tatters. He finds out that the way to make an honest living is to start from the bottom and work his way up the economic latter. To "take something you couldn't spend over money...." only highlights Johnson's misplaced idealism and sore understanding of money and capitalism. He may be clever, but as he performed in Two Trains Running, his bank robbery completed the circle of misdeeds based on alleged, honorable actions. In reality, the Johnson of the present day is much more adept at taking advantage of opportunities.

Though this may be a detriment, the fact that he is a self-made contractor for the people of Pittsburgh puts him in a category of a productive being. As Caywood and Floyd propose, "there are possibilities of redemption..." for characters like Sterling Johnson. While it has been decades since his release from jail, Johnson still has to prove himself to be a man of character and promise. Wilson imbues in him a thought of how you can grasp that brass ring in America and hold it, even if you fell off of the carousel once or twice. Sterling Johnson is a fine and upstanding citizen of Pittsburgh after his time spent in prison. The trio of crimes related to Sterling Johnson represent the recidivism of the convicts in America. Sterling fosters a new sense about himself as a reformed inmate, but 
the penitentiary never leaves his mind. It is a constant battle for him to remain on the right side of the law before his regressive tendencies return.

Old Joe who is also mentally unstable (a staple in Mr. Wilson plays) also spent several stints incarcerated. His rap sheet, read by Roosevelt states that among other charges, Old Joe committed "vagrancy...[theft] of a crate of chickens...spent eight months on the county farm...and breaking and entering." Old Joe exhibits wisdom throughout the play, but it is like the wisdom of the Shakespearean fool because of his psychological instability. Through the years, he's been hospitalized and incarcerated because of this ailment.

Old Joe presents the truth to Roosevelt and Harmond. His past reflects his mental state. He holds the keys to the play because of his many experiences whether they be behind the walls of psychiatric institutions or legal structures. As he imparts "game" to his listening audience, he is able to tell his tales because of all of the times that he had been on the wrong side of the law or gone through dealing with mental health professionals. Old Joe is the consummate figure that broadcasts the truth but in a way that seems gnarled, twisted and incoherent on its face. In reality, his words stand out as nuggets of thought that remain platinum to the growing mind.

\section{The Women in Wilson's Plays Bear the Weight of Systematized Incarceration}

The women in Mr. Wilson's plays bear the heavy weight of the systematized incarceration practiced in the United States after slavery. Rose takes in Troy in Fences, Tonya takes in Hedley II in King Hedley II, and Berniece watches over all the ex-prisoners in The Piano Lesson. Each of these women stand as towering figures in Wilson's world. It is the women and children who must bear the brunt of the issue when a man goes to prison or gets out of those circumstances. The women provide the love and encouragement and even bear the anger and frustration of the ex-convict. They must take upon themselves the pain and anguish that the man carries with him. These women are more than strong. Their strength is far superior than that of the men with whom they share their homes, their beds, their lives. It's Aunt Ester who herself sees some jail time that straightens out the Black men about the City of Bones. The women of the Twentieth Century Cycle represent the spinal column of the August Wilson universe. They stand up erect and allow their own voices to be heard. They give a perspective that is unique and profound. Their songs lift spirits and their arguments punch guts. Every woman that graces the stage in an August Wilson play more often than not deals with a felon. They strive to communicate their own status in life and what their wants and needs are. The power and the glory of August Wilson's women calls for these beautiful flowers to inspire their respective men and continue to express fidelity to them, even when fidelity is not reciprocated.

Women in August Wilson's plays remain stalwarts throughout the Cycle. Their participation in the lives of their children and the men who have been out of prison allows them to connect with the men in their lives with justice while still holding onto their independence. Women continue to be the stanchions to all of Mr. Wilson's works, especially when an ex-con is involved.

\section{Conclusion}

In all, August Wilson has created a monumental portrait of Black America that illustrates how Black men are often prison bound, currently in prison, or have recently left prison. The words and work of these Black people is what Mr. Wilson strived to convey. For the characters who saw prison walls and barbed wire in an oppressive environment, Mr. Wilson treats them with dignity, honor, and respect.

From Troy Maxson to Levee and from Solly Two Kings to Sterling Johnson, all of these men are represented with the fullest amount of honesty and integrity. It is to Mr. 
Wilson's credit that he molded these men to speak their truths out loud. Some of them are boastful and boisterous while others harbor quiet frustration that lingers for decades. The connection between Black Americans and the penal code has been examined through novels, other stage plays, and film. But no other author has positioned the Black man against the trials and travails of being released or entering the walls of justice with such ferocious elegance and poise.

Mr. Wilson brings to the stage the voices of the pained, the hurt, the forgotten. When Loomis loses his song, it is the song of millions of Black men who have tried to hold onto their song. It gets stuck in their throat and they're unable to belt out with full thought and emotion their struggle. But like Loomis, it is still possible to find that sacred song. Now, Caesar, Levee and Hedley may be some of the most vicious men in Wilson's canon. While he presents them with an objective mind, he notes just how cruel the men can be even if one of them suffers from a mental incapacitation. These men voice aloud what bothers them, what excites them, what drives them. Mr. Wilson has provided a platform for Black men to be counted in a society that sometimes does not see them. This is especially the case if they are ex-cons. The turbulent judicial system is designed to break down the individual. Mr. Wilson offers enough monologues and dialogues of these former prisoners to send home the message that it is not always too late to seek absolution.

Black men bond and find solace in the characters presented by Mr. Wilson. There's a catharsis that occurs when men of color view these works. These men take to the plays their own hurts and experiences of racism and prejudice. They can receive the words and actions and apply them to their own lives. They can see a Levee and not act out his indignation but understand his words against faith and the vile acts perpetrated against his mother and himself. The Black men who witness these plays can reap great benefits from the spoken words of these characters.

Possibly the most tragic case is King Hedley. He had just gotten out of the "joint" and looked for the few prospects open to a rehabilitated convict. His plight pits him against his girlfriend, his mother, and friend. He perishes early and there's no one to tell him how much he was respected and loved. Mr. Wilson never hesitated to bring sorrow and sadness to a project whether it is Fences or Joe Turner's Come and Gone. He gives the audience the opportunity to delve into the lives of these characters and make up in their own minds who is moral, who is virtuous, who is just. The answers might surprise some. The life lessons that Troy Maxson airs out to Rose, Bono, Cory and Lyon are from a place of deep hurt and agitation. But Mr. Wilson inculcates in Maxson with a sense that he is playing a baseball game with Death and he is trying to win for all eternity. That is the key to all of Mr. Wilson's works. It is the attempt, the striving to do the best, to live the best, to love the best, to be the best, despite challenges and limitations.

Given their sometimes humble jobs and their modest situations, these men related to the penitentiary excel beyond their circumstances. As opposed to just settling for their shortcomings, the men of August Wilson's plays rise above their stations and search for meaning in life. Their character is what sets them apart from just being common thugs. They have full, rounded souls that exude from the stage. The fact that they are due for their day behind bars or have been released decades ago does not negate their mission of selfdefinition, self-enlightenment, and self-fulfillment. Each man tied to a chain gang or the past injustice of going to jail for self-defense has his own story to tell. With exuberance and pathos, with passion and conviction, these men relate their tales.

The demise of George Floyd and Breonna Taylor ${ }^{4}$ among so many others only intensifies the work of August Wilson and other writings about the American carceral

\footnotetext{
${ }^{4}$ Breonna Taylor was a Black American woman who was fatally shot by officers of the Louisville Metro Police Department (LMPD) on March 13, 2020. The attorney general of the state of Kentucky was still investigating as this article was being edited for publication.
}

$\begin{array}{lll}\text { augustwilson.pitt.edu } & \text { DOI 10.5195/awj.2020.55 ISSN 2577-7432 (online) }\end{array}$


system and police force as they relate to black life—and death—in America. Mr. Wilson shows that the joys and triumphs must be remembered along with the sorrows and harshness of life. Like candles snuffed out by literally choking or gunning down, the Cycle gives all the anger, frustration, sadness, glory, honor, and power through the language and acts of the Blacks who populate August Wilson's plays.

August Wilson's carceral men continue to be topics of discussion as the irony of the most moral country in human history has the highest incarceration rate. And among those incarcerated in large numbers are Black men. Mr. Wilson attempted to put a central nervous system, flesh, blood, bone, and brains into the characters that he sets on a page, stage, and screen. He breathed life into every one of them and moved out of the way when they started talking about their lives. It is similar to what the playwright said himself, "Confront the dark parts of yourself, and work to banish them with illumination and forgiveness. Your willingness to wrestle with your demons will cause your angels to sing."

Editor's Note:

Below is a list of the number of times the word "jail" appears in each August Wilson play (tallied July 4, 2020). This is an initial count and is subject to correction.

References to "prison" are more limited and would involve a separate tally. References to Parchman Farm and Joe Turner's work farm are also present but would, themselves, involve a separate tally.

Michael Downing, Editor

August Wilson Journal

In written order:

Jitney: 1

Ma Rainey's Black Bottom: 2

Fences: 2

Joe Turner's Come and Gone: 3

The Piano Lesson: 5

Two Trains Running: 12

Seven Guitars: 13

King Hedley II: 22

Gem of the Ocean: 11

Radio Golf: 15

How I Learned What I Learned: 15

\section{Works Cited}

Bauder, Bob. "Ex-Cons Learn Trade Turning August Wilson's Childhood Home into Arts Space." TribLIVE.com, Trib Total Media, LLC, 24 Dec. 2014, https://archivetriblive.com/local/pittsburgh-alleghany/ex-cons-learn-tradeturning-august-wilsons-childhood-home-into-arts-space/. Accessed 5 June 2019.

Caywood, Cynthia L. and Carlton Floyd. "She Make You Right with Yourself": Aunt Ester, Masculine Loss and Cultural Redemption in August Wilson's Cycle Plays," College Literature, Johns Hopkins UP 9 Apr. 2009, muse.jhu.edu/article/262599. Accessed 5 June 2020. 
Morrison, Toni, “Foreword to The Piano Lesson." Theatre Communications Group, 2007.

Hedges, Chris. The Play's the Thing. 17 June 2014, billmoyers.com/2013/12/18/the-plays-thething/.

NAACP: U.S. Prisons Funded At Expense Of Education. 7 Apr. 2011, www.npr.org/2011/04/o7/135209942/naacp-u-s-prisons-funded-at-expense-ofeducation.

Smith, Kyle. “August Wilson's Cycle of bloodshed” The New Criterion, newcriterion.com/issues/2017/3:august-wilsons-cycle-of-bloodshed. Accessed 5 June 2020 .

Wardi, Janine Anissa. “The Colored Man Can't Fix Nothing with the Law”: Carceral Spaces in August Wilson's 'The Piano Lesson." Journal of African American Studies, vol. 17, no. 4, 2013, pp. 506-517. JSTOR, www.jstor.org/stable/43525524. Accessed 5 June 2020 .

Wilson, August. Fences. New York, Theatre Communications Group, 2007.

---. Gem of the Ocean. New York, Theatre Communications Group, 2007.

---. Jitney. New York, Theatre Communications Group, 2007.

---. Joe Turner's Come and Gone. New York, Theatre Communications Group, 2007.

---. King Hedley II. New York, Theatre Communications Group, 2007.

---. Ma Rainey's Black Bottom. New York, Theatre Communications Group, 2007.

---. The Piano Lesson. New York, Theatre Communications Group, 2007.

---. Radio Golf. New York, Theatre Communications Group, 2007.

---. Seven Guitars. New York, Theatre Communications Group, 2007.

---. Two Trains Running. New York, Theatre Communications Group, 2007.

Witherspoon, Williams H.W. Kimmika. "Challenging the Stereotypes of Black Manhood: The Hidden Transcript in Jitney." August Wilson: Completing the TwentiethCentury Cycle. U of Iowa P. 2010. Accessed 5 June 2020.

Zhang, Hongmei. “August Wilson's Otherness in Joe Turner's Come and Gone.” Theory and Practice in Language Studies 6 (1): 171 Jan. 2016. Accessed 5 June 2020.

\section{Author Bio}

Skyler Easton Saunders is a forever-young, ego-driven radical hipster from Delaware. His current project involves writing a for the Vocal Media website where he "conveys to the world an objective viewpoint on any subject [he] encounters."

Link: https://vocal.media/authors/skylerized 
S A U N D E R S: U N L O C K E D M I N D S: A U G U S T W I L S O N'S

S U S P E C T S, EX-CON S, OR S O O N-T O-B E C O N VICTE D

CHARACTERS IN HIS AMERICAN CENTURY CYCLE

August Wilson Journal| Vol.2

Articles in this journal are licensed under a Creative Commons Attribution 4.0 International License.

ULS This journal is published by the University Library System of the University of Pittsburgh as part of its D-Scribe Digital Publishing Program and is cosponsored by the University of Pittsburgh Press. 